\title{
FRONTEIRAS ABERTAS PARA LÍNGUAS E CULTURAS ESTRANGEIRAS: QUANDO É QUE UMA NAÇÃO ASSUME ESSA ATITUDE? ${ }^{1}$
}

\author{
Lenita M. Rimoli Esteves
}

Em tempos de globalização e posturas anti-hegemônicas, geralmente se vê com bons olhos uma nação que acolhe influências e características de outra nação estrangeira. No campo da teoria da tradução, o exemplo mais conhecido é o dos intelectuais alemães que atuaram na época do Classicismo e do Romantismo. De formas não idênticas, esses autores adotaram como política uma postura de "expandir os limites da língua nacional”, acolhendo influências e traços de outras culturas. O movimento se deu eminentemente na literatura, e foi promovido por autores como Göethe, Schleiermacher, os irmãos Schlegel, Tieck, entre outros. Liderança intelectual na Alemanha de sua época, esses autores foram também eminentes tradutores que empreenderam significativos projetos de tradução. August Wilheim Schlegel (1767-1845) empreendeu, em parceria com Ludwig Tieck (17731853) e outros colabores, a tradução de várias obras de Shakespeare, que são consideradas por alguns como o maior feito do Romantismo Alemão. ${ }^{2}$ Além disso, Schlegel foi o responsável pela tradução de obras de Cervantes, Calderón, Petrarca, bem como várias obras em espanhol e português (v. Berman [1984] 2002: 27). Schleiermacher (1768-1834) traduziu Platão; Goethe (1749-1832) traduziu Diderot; e Hölderlin (1770-1843) traduziu Sófocles e Píndaro. O trabalho deste último é considerado por alguns como lance de gênio e por outros como fruto de uma mente perturbada.

Esse momento especial da história da literatura alemã foi relembrado e celebrado pelo teórico francês Antoine Berman, que em A prova do estrangeiro ([1984] 2002) classifica a postura desses autores e poetas alemães como "a postura ética” a ser seguida em qualquer empreendimento tradutório. Berman classifica a tradução etnocêntrica como

\footnotetext{
${ }^{1}$ Este trabalho foi apresentado em formato de comunicação oral durante o I Congresso Internacional da ABRAPUI, realizado na UFMG, em Belo Horizonte, em julho de 2007.

${ }^{2}$ As peças traduzidas foram, entre outras, Romeo and Juliet, A midsummer night's dream, Julius Caesar, Twelfth night, The tempest, Hamlet, The merchant of Venice, As you like it, King John, Richard II, Henry IV, Henry V, Henry VI e Richard III. O projeto se desenvolveu entre 1797 e 1810. (v. http://www1.bartleby.com/215/1220.html, acesso feito em 30/05/2007)
} 
antiética e danosa. O importante é, independentemente da época e das culturas em questão, “esticar as fronteiras da língua” para receber a contribuição estrangeira.

É interessante observar que Berman, de nacionalidade francesa, tenha escolhido como modelo de abordagem ética na tradução a experiência alemã do século 19; ele que, em seu país, com certeza conheceu a tradição das belles infidèles, na qual os tradutores de literaturas estrangeiras para o francês “adaptavam” o texto para torná-lo palatável ao gosto francês da época. Em outras palavras, os franceses primaram tradicionalmente pela estratégia oposta à defendida por Berman. Um dos exemplos emblemáticos dessa prática foi o tradutor Ducis, que no século 18 traduziu várias peças de Shakespeare deixando de lado tudo o que julgava bárbaro ou inadequado: frases de duplo sentido com conotações sexuais, cenas violentas, entre outras, visando a agradar ao público francês, que não podia suportar o barbarismo de Shakespeare (v. Milton, 1993: 49-52; http://www.bartleby.com/215/1215.html).

Um dos principais motivos para Berman escolher os alemães como modelo de ética tradutória não etnocêntrica é o fato de a tradução da Bíblia feita por Lutero ser um texto fundador da cultura e da língua alemã moderna. Ou seja, um dos textos fundadores da cultura alemã moderna é uma tradução. Entre 1521 e 1534, Lutero e sua equipe de eruditos trabalharam na tradução que foi a pedra angular da Reforma protestante. Lutero propôs-se a escrever um texto que fosse acessível ao povo, em um "bom alemão”, que acabou se transformando também no alemão literário. Naquela época, na Alemanha conviviam vários dialetos, e Lutero conseguiu unificar e consolidar a língua alemã em seu texto bíblico. Ao mesmo tempo, Lutero, escrevendo a Bíblia em alemão, manifestava sua revolta contra o latim e o poder da Igreja romana representado por essa língua. Dessa forma, a Bíblia de Lutero inaugura uma nova fase da nacionalidade alemã. Nas palavras de Berman:

Se a Bíblia de Lutero desempenha esse papel, é porque ela acredita ser uma Verdeutschung das Escrituras ligada historicamente a um vasto movimento de reformulação da fé, de renovação da relação com os textos sagrados, de reinterpretação radical dos Testamentos, assim como a uma afirmação religiosa nacional em face do "imperialismo" de Roma. Inversamente, esse movimento só adquire toda sua força pela existência efetiva de uma Bíblia "germanizada" e acessível a todos. Há nisso uma conjuntura histórica e cultural decisiva, que instaura na Alemanha um verdadeiro corte: há de agora em diante um antes e um após Lutero, não somente religiosa e politicamente, mas também literariamente. (Berman, [1984] 2002: 53) 
Antes de examinarmos mais de perto o caso da tradução na Alemanha, faço uma pausa para fazer algumas interrogações: até que ponto é possível não ser etnocêntrico? No limite, a cultura receptora, acolhendo as influências estrangeiras, não correria o risco de perder sua identidade? O que efetivamente significaria "esticar as fronteiras da língua” e receber as influências estéticas e culturais da língua estrangeira? Em que ocasião ou ocasiões uma nação aceita adotar uma postura assim tão liberal e tolerante? Passemos a alguns outros casos.

Pode parecer estranho, mas a Inglaterra viveu uma fase em que o traduzir era um ato de patriotismo e a tradução foi usada como estratégia para enriquecer a cultura do país. Segundo F. O. Matthiessen, no período elizabetano os ingleses sentiam-se culturalmente inferiores em relação a alguns países do continente europeu, e empreenderam traduções em grande escala para igualar-se aos espanhóis, franceses e italianos. Nas palavras do autor:

The nation had grown conscious of its cultural inferiority to the Continent, and suddenly burned with the desire to excel its rivals in letters, as well as in ships and gold. The translator's work was an act of patriotism. He, too, as well as the voyager and merchant, could do some good for his country: he believed that foreign books were just as important for England's destiny as the discoveries of her seamen, and he brought them into his native speech with all the enthusiasm of a conquest. (Matthiessen, 1931: 3)

Mesmo assim, o fato de a Inglaterra em determinada época considerar que importar obras estrangeiras era uma maneira de enriquecer sua cultura não significou que as traduções produzidas nessa época fossem "não etnocêntricas” na classificação de Berman. Houve, nesse esforço tradutório, uma estratégia de franca acomodação do texto estrangeiro aos valores locais:

An important thing to remember from the outset is that the Elizabethan translator did not write for the learned alone, but for the whole country. He possessed a style admirably fitted to this end. Popular in the best sense, it took advantage of all the new richness of the language. His diction was racy and vivid, thronged with proverbial phrases, the slang of the streets, bold compounds, robust Saxon epithets, and metaphors drawn from English ports and countryside [...] Whenever possible he substituted a concrete image for an abstraction, a verb that carried the picture of an action for a general statement. The result was an increased liveliness, a heightened dramatic pitch that often carried the words into a realm of imagination and feeling unsuggested by the original. Theoretically there may be no defense for such a method of translating, but in practice it succeeded as no other method could. For it made the foreign classics rich with English associations; it took Plutarch and Montaigne deep into the national consciousness. (Matthiessen, 1931: 3-4) 
É possível então observar que, embora os ingleses considerassem nessa época que sua cultura era "inferior", suas traduções de obras estrangeiras eram recheadas de elementos da cultura de chegada, inclusive com falas e expressões que não necessariamente pertenciam a uma elite cultural. As "políticas tradutórias” desse período se assemelham em parte às da França (no sentido da acomodação ao gosto da língua de chegada), e em parte à dos alemães (no sentido de buscar enriquecer sua cultura com influências de outros países). Houve situações mais recentes em que determinadas nações adotaram como política cultural a tradução em massa, para criar um modelo literário para o país receptor. Foi o que aconteceu na Terra de Israel durante o domínio britânico, entre 1918 e 1948, data em que foi instituído o Estado de Israel. A adoção do hebraico como língua oficial, além de contrariar alguns religiosos ortodoxos que não concordavam que uma língua antes considerada sagrada passasse a ser usada no dia-a-dia, trouxe um problema: não havia literatura em hebraico. Para preencher essa lacuna, a sociedade israelense da época optou por realizar muitas traduções de obras literárias de vários países, na tentativa de criar um "substrato" a partir do qual pudesse surgir uma literatura original em hebraico.

Zohar Shavit cita, em seu estudo sobre o assunto, as palavras de Jacob Steinberg, segundo o qual "não falta nada em um lugar que possui textos de ficção, mesmo se esses textos de ficção forem traduções” (Steinberg, apud Shavit, 1998, s.p., tradução minha).

Entretanto, com o passar do tempo, o Estado de Israel começou a não ser mais tão receptivo à literatura traduzida. Na década de 1930, alguns eram da opinião de que a literatura estrangeira estava atrapalhando a produção de uma literatura original local. Um dos exemplos dessa mudança de ponto de vista foi Asher Barash, editor do jornal Hedim, que na década de 1910 tinha sido um franco encorajador da tradução de obras literárias estrangeiras, e agora passava a considerar que o grande empreendimento tradutório estabelecido em Eretz-Israel parecia "lançar uma sombra sobre a prosa original em hebraico, e reduzi-la a uma mera fração” (Barash, apud Shavit, 1998, s.p., tradução minha).

Processo semelhante ao de Israel foi observado na Turquia. Como narra Özlem Berk, esse processo teve início após a queda do Império Otomano, a partir de meados do século 19 e continuou durante todo o século 20. Já desde o período Tanzimat, que representou o final do Império Otomano e durou de 1839 a 1876, observou-se, segundo 
Berk, uma tendência à ocidentalização da Turquia, o que incluiu a tradução de obras literárias estrangeiras, principalmente do francês (v. Berk, 2006: 2). Tanzimat significa “reorganização", e o período se caracterizou, segundo Berk, como “o primeiro movimento consciente de ocidentalização na tentativa de modernizar o estado e a sociedade otomana" (Idem, idem).

O Tanzimat consistiu em uma série de reformas legais, administrativas, militares e educacionais, numa tentativa de encorajar o otomanismo entre os vários grupos étnicos que tinham objetivos separatistas. O movimento tentou integrar não-turcos e não-muçulmanos na sociedade otomana, por meio de liberdades e regulamentações civis.

No entanto, o esforço não proporcionou os resultados esperados e, em 1876, iniciouse a chamada "Primeira Era Constitucional”. Com a Proclamação da República em 1923, ainda segundo Berk, observou-se uma intensa atividade tradutória durante as primeiras décadas do novo regime político, na esteira de reformas políticas e culturais ocorridas na época.

Berk cita Ahmed Tanpinar, segundo o qual a falta de inovação na literatura do mundo islâmico devia-se principalmente à falta de modelos literários (v. Tanpinar, apud Berk, 2006: 3). Portanto, a nova literatura turca originária dessa ampla atividade tradutória inovou em termos literários, trazendo para a Turquia formas ocidentais, como o teatro e o romance (Id, id.). A nova identidade que a jovem república queria criar para seu povo se definia por ser secular, moderna e de orientação européia, e seus membros deveriam sentirse principalmente “turcos” (Idem: 6).

Essa atividade tradutória continuou durante várias décadas, mas na década de 1980 começou a haver um questionamento dos valores ocidentais. A única área da cultura ocidental que não encontrou resistência foi a de ciência e tecnologia (Idem: 13). Nessa mesma época, o povo turco passou a se definir não só em relação à Europa, mas também a outros continentes, como a América Latina. Ao mesmo tempo, observa-se uma “redescoberta da literatura nativa”. A literatura traduzida passa a ser bem mais variada, convivendo com uma literatura local mais forte, na qual florescem com energia os escritos feministas (Idem: 13-14). A partir da década de 1980, com a diversidade de gêneros e formas, a literatura turca passa a ser traduzida para o inglês e também para outras línguas 
(Idem: 15). A partir dessa época, a literatura traduzida passa a ter outra importância, pois convive também com uma produção nacional.

Como se pode notar, parece que é mais comum observar processos de grande importação de literatura estrangeira quando por algum motivo a literatura do país não está ainda consolidada, ou quando a nação se julga culturalmente “inferior” em relação a outras. Quando a identidade da literatura nacional ganha força, as obras literárias estrangeiras já não têm tanta importância e podem até ser consideradas um obstáculo ao desenvolvimento da literatura local.

Voltemos agora aos alemães: será que o caso deles é diferente? Será que os alemães continuaram a receber bem a influência estrangeira mesmo depois de perceberem sua cultura nacional mais bem-consolidada? Na opinião de Berman, sim e não. Talvez devido à importância da tradução na gênese de sua nação moderna, os alemães a consideravam, segundo Berman, de um modo também singular. Eles não eram nem totalmente subservientes, considerando-se inferiores a outras nações em termos culturais, nem impermeáveis às influências estrangeiras, como mostrou ser a tendência característica dos franceses.

Os alemães desejavam importar as obras literárias estrangeiras, mas para depois incorporá-las à sua própria literatura, num equilíbrio entre uma atividade centrífuga e uma atividade centrípeta, um trabalho que era um misto de estrangeirização e domesticação. A literatura, a língua e as formas estrangeiras serviriam para alargar as fronteiras do alemão, porém este último nunca deixaria de ser alemão. Poderia até transformar-se em uma superlíngua, uma espécie de língua franca da tradução. Observem-se alguns trechos citados por Berman em sua obra:

As outras nações aprenderão logo o alemão, porque perceberão que assim poderão se poupar, em uma certa medida, da aprendizagem de quase todas as outras línguas. De quais línguas, com efeito, não possuímos as mais eminentes traduções? (Goethe, apud Berman, [1984] 2002: 28)

Creio que estamos a ponto de inventar a verdadeira arte da tradução poética; essa glória estava reservada aos alemães. (A. W. Schlegel, apud Berman, [1984] 2002: 29)

A força de uma língua não está em rejeitar o estrangeiro, mas em devorá-lo. (Goethe, apud Berman, [1984] 2002: 29) 
Como se pode observar por esses poucos trechos, existe um esforço de absorver o estrangeiro, mas sem nunca perder o sentimento de nacionalidade, de germanidade. Tratase de um processo de incorporar o outro e mesclá-lo a si mesmo. É preciso, portanto, refletir um pouco mais a fundo antes de afirmar que os alemães, na época do Romantismo e do Classicismo, adotaram uma posição francamente não etnocêntrica. Talvez eles se sentissem tão seguros ao "esticarem as fronteiras da sua língua” e misturá-la com outras porque estavam convictos de que o alemão "triunfaria”. Nessa concepção canibalista do encontro entre culturas (sugerida pelo termo “devorá-lo”, empregado por Goethe bem antes, aliás, que o fizessem nossas vanguardas modernistas), não deixa de haver um forte traço de dominação, com a língua alemã incorporando o elemento estrangeiro e tornando-o parte de si própria.

\section{Referências bibliográficas}

BERMAN, Antoine ([1984] 2002) A prova do estrangeiro. Trad. de Maria Emília Pereira Chanut. Bauru: EDUSC.

BERK, Özlem (2006) “Translating the 'West': the position of translated Western literature within the Turkish literary polysystem”. Ri.L.Un.E, 07/2006, n. 4. Versão eletrônica http://www.rilune.org/mono4/Berk_Rilune4_2006.pdf, acesso feito em 30/05/2007.

MATTHIESSEN, Francis Otto (1931) Translation, an Elizabethan art. Cambridge: Harvard University Press.

MILTON, John (1993) O poder da tradução. São Paulo: Ars Poetica.

SHAKESPARE ON THE CONTINENT. The Cambridge history of English and American literature in 18 Volumes (1907-21).Volume V. The Drama to 1642, Part One. http://www1.bartleby.com/215/1220.html, acesso feito em 30/05/2007).

SHAVIT, Zohar (1998) "The status of translated literature in the creation of Hebrew literature in pre-state Israel (the Yishuv period)”. Meta, XLIII, 1. Versão eletrônica disponível em http://www.tau.ac.il/ zshavit/articles/(50)The_Status.pdf, acessado em 30/05/2007). 